IRA-International Journal of Management \& Social Sciences

ISSN 2455-2267; Vol.08, Issue 01 (July 2017)

Pg. no. 31-45

Institute of Research Advances

http://research-advances.org/index.php/RAJMSS

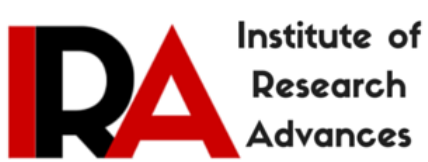

\title{
Effect of Human Resource Competencies, Information Technology and Internal Control Systems on Good Governance and Local Government Financial Management
} Performance

\author{
Nurmiati Irvan ${ }^{1,}$ Abdul Rahman Mus ${ }^{2}$, Muhammad Su'un ${ }^{3}$, Mukhlis Sufri ${ }^{4}$ \\ 1 Patria Artha University \& \\ Doctoral Student in Faculty of Economics, University of Muslim Indonesia, Indonesia. \\ 2,3,4 Faculty of Economics, University of Muslim Indonesia, Indonesia.
}

Type of Review: Peer Reviewed.

DOI: http://dx.doi.org/10.21013/jmss.v8.n1.p4

How to cite this paper:
Irvan, N., Mus, A., Su'un, M., \& Sufri, M. (2017). Effect of Human Resource Competencies, Information
Technology and Internal Control Systems on Good Governance and Local Government Financial
Management Performance. IRA-International Journal of Management \& Social Sciences (ISSN 2455-2267),
8(1), 31-45. doi:http://dx.doi.org/10.21013/jmss.v8.n1.p4

(C) Institute of Research Advances.

\section{(cc) BY-No}

This work is licensed under a Creative Commons Attribution-Non Commercial 4.0 International License subject to proper citation to the publication source of the work.

Disclaimer: The scholarly papers as reviewed and published by the Institute of Research Advances (IRA) are the views and opinions of their respective authors and are not the views or opinions of the IRA. The IRA disclaims of any harm or loss caused due to the published content to any party.

Institute of Research Advances is an institutional publisher member of Publishers Inter Linking Association Inc. (PILA-CrossRef), USA. The institute is an institutional signatory to the Budapest Open Access Initiative, Hungary advocating the open access of scientific and scholarly knowledge. The Institute is a registered content provider under Open Access Initiative Protocol for Metadata Harvesting (OAI-PMH).

The journal is indexed \& included in WorldCat Discovery Service (USA), CrossRef Metadata Search (USA), WorldCat (USA), OCLC (USA), Open J-Gate (India), EZB (Germany) Scilit (Switzerland), Airiti (China), Bielefeld Academic Search Engine (BASE) of Bielefeld University, Germany, PKP Index of Simon Fraser University, Canada. 


\begin{abstract}
This study aimed to analyze the effect of human resource competencies, information technology and internal control systems on good governance and local government financial management performance in the Indonesian local government (Pangkep South Sulawesi). Research conducted on civil servants working on 49 local work units (SKPD) by setting a sample of 245 respondents. Data were analyzed using Structural Equation Model (SEM) supporting through Analysis of Moment Structures (AMOS) Ver. 21. The results showed that the human resources competencies and internal control system have a positive and a significant effect on good governance. Information technology has positive but not significant effect on good governance. A human resources competency, internal control system and good governance have positive and significant effect on the financial management performance. Information technology has insignificant effect on financial management performance: The Mediating role of good governance.
\end{abstract}

Keywords: Human resource competencies, information technology, internal control systems, good governance, local government financial management performance

\title{
Introduction
}

Successful development of a region cannot be separated from the financial management aspects of the managed area with good management. Financial Management is the overall activities that include planning, implementation, administration, reporting, accountability, and financial oversight of the area, which is stipulated in the Regulation of the Minister of Home Affairs Number 13 (2006 Section 3) includes the power of financial management, general principles and structure of the Regional Government Budget (APBD), the drafting of the budget, determining the budget, preparation and adoption of the budget for areas that do not have a parliament, implementation of the budget, changes to the budget, cash management, financial administration area, financial accounting area, accountability of the budget, the guidance and supervision of financial management, a loss of area, and financial management of local public service Agency (BLUD). Financial management should be managed in an orderly, obedient to laws and regulations, effective, efficient, economical, transparent, and accountable under the principles of fairness, decency, and the benefits to society.

The phenomenon that occurs in the Indonesian local government (Pangkep) of the activity planning and budgeting has not been prepared well where coordination between SKPD for planning was still weak, then from the implementation of which is the implementation of activities often retreat from the planned schedule, and then on the side of the administration is still their incomplete documents and administrative errors still occur. Financial reporting areas are still often delayed their terms of accountability still some activities that are not targeted. Similarly, in terms of financial supervision is still weak which is still their findings in the implementation of activities in the field.

Financial performance on Indonesian local government (Pangkep) is not optimal, the implementation of good governance that has not been the synergy of all local work units (SKPD). Some previous researchers provide evidence that good governance has a positive and significant effect on the performance of financial management (Husmaruddin, 2015). Implementation of the principles of good financial governance in the legislation relating to public finance management can establish good governance (Indrawati, 2012). Implementation of good corporate governance will yield good financial performance (Igor Todorovic, 2013). Implementations of good governance have a significant effect on the financial performance of the organization (Sri Fadilah, 2013). The findings of some researchers obtain denials from other researchers that good corporate governance is no significant effect on the financial performance (Makki \& Lodhi, 2014).

The weakness of the competence of human resources (financial management staff in Pangkep) resulted in the implementation of good governance and financial management performance is not optimal. Some researchers provide evidence that the individual competencies of a significant effect on the financial performance of government (Manaroinsong, 2012). Managerial competence is positive effect on governance and financial performance (Abbas, 2013). Human resources have a tremendous influence on the financial performance (Majuta, 2014). The findings of some researchers obtain contradiction of other researchers, that the quality of human resources not significant effect 
on the quality of local government financial statements (Dadang, 2015). Managerial competence has insignificant effect on financial performance of local governance (Grace, 2013).

In order to carry out financial accountability, local governments have a duty to use information technology in order to simplify the process of managing financial data. Empirical evidence shows that the use of information technology and good corporate governance has a positive and significant impact on the reliability of financial reporting of government (Prasetyo, 2014). A capability of information technology has a significant relationship with organizational performance (Kabiru et al., 2015). The uses of information technology systems have a positive impact on the quality of local government financial statements (Rahman \& Fachri, 2016). The findings were obtained denials from other researchers, that the uses of information technology within government organizations have not been able to support good governance. Use of information technology is not in the framework of good governance but it is only used as a tool to facilitate the work alone (Wigrantoro, 2003). Information technology has not significant effect on the quality of local government financial statements (Dadang Suwanda, 2015).

Other factors that influence the governance, is the internal control to employees, which are very vulnerable to errors either intentional or unintentional (Mahmudi, 2007: 27). Internal control systems are not yet fully implemented integrally in Indonesian local government (Pangkep) as yet make environmental controls over financial activity conducted, has not made an assessment of the financial risks that may arise from any activity, yet effective system of information and communication, not optimal in the implementation of financial procedures and still lack of monitoring of the various activities implemented. As a result of the internal control system which has not done well yet optimal impact on the implementation of good governance and Indonesian local government financial management performance (Pangkep)

Findings from previous research, providing the implementation of effective internal control is very important in supporting on good corporate governance (Kosmas et al., 2011). Internal control systems affect the performance of local government financial management (Rosma, 2014). The findings were obtained from investigators rebuttal others, that the qualities of the internal audit no significant effect on the performance of the local government (Obal \& Salim, 2016). Internal audit does not improve government performance (Rhodah, 2014). Internal control system has insignificant impact on financial performance through good governance (Julie, 2015).

\section{Literature review}

\section{Agency and Stakeholder theory}

The agency problem in public sector organizations is a concept that is based on agency theory. In financial reporting, the government acts as an agent has the obligation to present information that is useful for users of financial information the government acting as a principal in assessing accountability and make a good decisionmaking of economic, social and political as well as either directly or indirectly through their representatives. In a democratic government, the relationship between the government and the users of government financial information can be described as an agency relationship. The agency relationship is a working relationship between the parties authorizes (principal) with those who received the authority (agent) in the form of employment contract (nexus of contract) has been agreed (Jensen \& Meckling, 1976).

Public accountability as the obligation of a agent to provide accountability, presenting, reporting and disclose all activities and activities that are its responsibility to the mandate giver (principal) who has the right to ask those responsible. Public accountability is composed of two types, namely: 1) accountability for the management of the fund to a higher authority (vertical accountability), and 2) accountability to the public (horizontal accountability) (Mardiasmo, 2004: 20). Government as an authority in the wheels of government should emphasize this aspect of the people's interests as stakeholders and the government must also be able to manage regional assets, income and the form of regional assets for the welfare of the people in accordance with the contents of the Act of 1945, article 33 which states that all natural resources controlled by the government should be used and utilized for the welfare of the people. Stakeholders as any group or individual who can affect be affected by the achievement of an organization's objectives (Freeman, 1984: 25). 


\section{Human Resources competencies}

Competence is a characteristic of someone who has the skills (skills), knowledge (knowledge) and capability (ability) to carry out a job competency is an underlying characteristic of a person achieve high performance on the job. Employees who do not have sufficient knowledge of the work will be a lot of obstacles that result in waste of materials, time and labour (Hevesi, 2005: 213). Competency is an underlying characteristic of an individual's roommates is causally related to criterion - referenced effective and or superior performance in a job or situation (Spencer \& Spencer, 1993: 9). Underlying Characteristics implies competence is part of a profound personality and inherent to the person and behaviour that can be predicted in a variety of circumstances and the job duties. Related causally means competency is something that causes or predict the behaviour and performance. Criterion Referenced implies that the competencies actually predict who is performing well, measured by criteria or standards used.

Based on the Indonesian Government Regulation No. 101 (2000, Article 3) states that competence is the capacity and characteristics of civil servants (PNS), in the form of knowledge, skills, and attitudes necessary behaviour in the execution of his duties. An assessment of the achievement of competencies needs to be done objectively, based on the performance of employees in the organization, with evidence of their mastery of the knowledge, skills, values and attitudes as a result of learning (Sutrisno, 2009: 223).

Employees who work at the working unit should have employees who are competent, who are supported by the educational background of accounting, often take part in education and training, and have experience in the financial sector so as to implement the accounting system, human resources has these competencies will be able to accounting logic is well understood. The failure of the government human resources in understanding and applying the accounting logic would have an impact on the financial statements that were made in error and discrepancy reports with the standards set by the government.

Measurement of employee competency in this study developed a competency measurement of Spencer \& Spencer (1993: 9), which includes: (1) Motives, (2) Traits, (3) Self Concept, (4) Knowledge, and (5) Skills. Empirical evidence suggests that the managerial competencies positive effect on governance (Abbas, 2013). The findings were obtained denials from other researchers, that the Auditor Competency have a negative impact and not significant to governance (Hidayat, 2013). Individual competencies significant direct effect on the financial performance (Manaroinsong, 2012; Abbas, 2013; Majuta, 2014). The findings are in contrast to other researchers, that the quality of human resources is not significantly impact on the quality of local government financial statements (Dadang, 2015), Auditor Competency have a negative impact and no significant effect on the financial performance (Hidayat, 2013; Prasad, 2014). HR capacity has positive and significant impact on the timeliness of financial reporting (Prasad, 2014)

\section{Information Technology}

Information technology is not only used in business organizations but also on public sector organizations, including in the field of governance. The use of information technology will be able to improve the performance of local government officials as well as in preparing financial reporting. The use of information technology is expected to improve the quality of information in financial reporting is mainly concerned with the reliability and timeliness of delivery aspects of financial reporting (Lestari \& Zulaikha, 2007: 15).

Government at central and local level are obliged to develop and exploit advances in information technology to improve the financial management capabilities, and deliver financial information to the public service. The government needs to optimize the utilization of advances in information technology to build a network of information management systems and work processes that allow the government to work in an integrated manner by simplifying access between units. Wilkinson (2000: 160) said their use of information technology include (a) data processing, information processing, management systems and work processes electronically and (b) the use of advanced information technologies so that public services can be accessed easily and inexpensively by the community.

Theory of Reasoned Action (TRA) explains that someone will use information technology if the technology useful and can improve the performance of such person (Fishbein \& Ajzen, 1975). In conjunction with the accounting information system, the computer will increase the capabilities of the system, when computers and components related to information technology is integrated into a system of accounting information, there is no common activity that is increased or decreased. The theory of attitude and behaviour developed by Triandis (1980) that the use of 
technology related to the behaviour of using the technology to complete the task, where the use of a personal computer or PC (Personal Computer) by users who have the knowledge, workplace utilize computers, habit (habit) in connection with the use of computers, and the conditions that facilitate (facilitating conditions) in a conducive environment utilizing a computer.

Explanation of the information technology constructs as the use of an application system that can be support the preparation of financial statements in a timely, complete, accurate, and reliable according to applicable regulations. Indicators Information technology refers to the use of information technology theory by Widjayanto (2001: 89) as follows: (a) Hardware; (b) software; (c) Management of data; and (d) Network.

Previous research findings indicate that the use of information technology systems have a positive impact on the quality of local government financial statements (Rahman \& Fachri, 2016). Use of information technology does not significantly impact on the quality of local government financial statements (Dadang, 2015). The rebuttal evidence obtained from other researchers, that the capability of information technology has a significant relationship with the financial performance of the banking organization (Kabiru et al., 2015; Rahman \& Fachri, 2016). Utilization of information technology has a positive and significant impact on the reliable of financial reporting government and precisely the time of reporting (Prasetyo, 2014). Use of information technology is not in the framework of good governance but it is only used as a tool to facilitate the work alone (Wigrantoro, 2003).

\section{Internal Control System}

Internal controls are Internal control is an integral process that is effected by an entity's management and personnel and is designed to address risks and to provide reasonable assurance that in pursuit of the entity's mission, the following general objectives are being Achieved, (a ) executing orderly, ethical, economical, efficient and effective operations; (b) fulfilling accountability obligations; (c) complying with applicable laws and regulations; safeguarding resources against loss, misuse and damage (International Organization of Supreme Audit Institutions, 2004: 6).

Financial management of government organizations, the system of control is needed is both the internal control system and control system external always take into account the improvement of environmental improvement organization, anticipating possible risks in the activities and financial transactions, to control procedurally by the rules, control with transparent information and accountable, and monitored in a controlled manner. The definition of internal control defined by COSO, adopted by the Indonesian Republic government based on government regulation Number. 60 Year 2008 on SPIP (Internal Control System of the Government) which gives the sense that SPIP is a process that is integral to the actions and activities that are carried out continuously by the management and all employees to provide reasonable assurance for the achievement of organizational goals through effective and efficient, reliability financial reporting, the safeguarding of state assets, and compliance with laws and regulations. SPIP is a control activity mainly on the management information system that aims to ensure the accuracy and completeness of the information.

The construct of the internal control system is described as a system of controls designed to ensure that all financial activities goes according systems and procedures. Indicators of the internal control system of internal control refers to the theory by The Committee of Sponsoring Organizations of the Treadway Commission, COSO (1992), include; (a) The control environment; (b) risk assessment; (c) control activities, (d) Information and communication; and (e) Monitoring. The results of previous studies, shows that the internal control effectively is essential in supporting good corporate governance (Kosmas et al., 2011; Shah, 2012) Internal control system is not significant influence on the quality of the financial statements of local government (Ashmir Shah, 2012; Rhodah, 2014; Dadang, 2015). The rebuttal evidence obtained from other researchers, that the internal control of accounting has a positive and significant impact on the reliability of financial reporting government (Prasetyo, 2014; Rosma, 2014; Obal \& Basariah, 2016).

\section{Good Governance}

Governance translated as governance is an authorized use of economic, political and administrative order to manage the affairs of the state at all levels. Governance covers all the mechanisms, processes and institutions where citizens and community groups give priority to their interests, using the legal rights, obligations and bridging the differences between them. Others cite the view governance as a mechanism of resource management involving the economic 
and social influence of the state sector and non-governmental sector in a collective effort. This definition assumes many actors involved where there is no dominant that determine the motion of other actors (Winarno, 2002: 122).

Governance is a process of social and political interaction between government and society in various fields relating to the public interest and government intervention on those interests (Kooiman, 1993: 224). Mechanisms, processes and institutions through citizens articulate their interests, mediate their differences and exercise their rights and their legal obligations (Setiawan, 2004: 12). Another view, as presented The United Nations Development Program (UNDP) (2000) defines good governance as the exercise of political, economic, and administrative authority to manage a nations affairs at all levels. World Bank defines good governance as the way state power is used in managing economic and social resources for development and society. Based on such understanding, the functional aspects of good governance can be evaluated from whether the government has to function effectively in order to achieve the objectives that have been outlined, or just the opposite where the government is not functioning effectively and inefficiency (Kurniawan, 2005: 14),

Based on some view of scholars, then good governance can be summarized as a method or means of financial management by applying the principles of good governance in the field of financial management. Indicators of good governance refers to the United Nations Development Program (UNDP) (2000) as follows: (a) participation; (b) law enforcement; (c) transparency; (d) responsibility; (e) consensus; (f) justice; (g) the effectiveness and efficiency; (h) accountability; and (i) the strategic vision. Empirical evidence shows that good governance is a positive and significant effect on the performance of financial management (Sri Fadilah, 2013; Igor Todorovic, 2013; Prasetyo, 2014; Husmaruddin, 2015). The findings were obtained denials from other researchers, that good corporate governance is not a significant effect on the financial performance (Makki \& Lodhi, 2014).

\section{Financial Management Performance}

Performance measurement system is usually done because of the problems the agency (agency problem), the manager of programs and activities tend to do things that benefit himself regardless of the principal parties. This phenomenon prompted the boss or supervisor to implement performance measurement systems so that the principal (employer) can overseen the management of programs and activities run the program and activities and have the schema in the setting of incentives and disincentives. Performance measurement also serves as a means to ensure the public interest can be maintained. Minister Regulation No. 21 (2011, Article 1), paragraph 6 of the Guidelines for Financial Management defines local finance as all the rights and obligations of the regions in the context of regional governance that can be valued in money includes all forms of property-related rights and obligations of the area. Finance area can simply be defined as all the rights and obligations that can be valued in money, as well as everything in cash or items that can be used wealth to the extent not owned / controlled by the state or the higher regions as well as the other parties in accordance with applicable of the law (Halim, 2002: 19). Performance is the quantity and quality of the work completed by an individual, group or organization (Stoner, 2006: 477). Performance as a result of work that can be achieved by a person or group of people within an organization in accordance with the authority and responsibilities of each in order to achieve organizational goals legally, do not break the law and in accordance with moral and ethical (Prawirosentono, 2008: 2).

In the context of local government organization, performance measurement local work units (SKPD) were conducted to assess how well the SKPD perform the duties and functions delegated to him for a certain period. Performance measurement of SKPD is a form of vertical accountability, which is evaluating the performance of subordinates by superiors and as a horizontal ingredients local government accountability to the public that the mandate given to him. According Henderson et al. (2002) suggests there are indicators of performance measurement of non-profit organizations, among others; (a) customer focused; (b) balanced; (c) timely; (d) cost effective; (e) compatible and comparable.

Financial management performance of local government in this study is mentioned as the level of achievement of a work in the financial field area that includes revenue and public spending using the financial indicators stipulated through a policy or statutory provisions during the budget period. Performance measurement in this study developed a measurement Halim (2004: 24), namely; (a) the financial independence of the region; (b) the reliance of local finance; (c) The degree of fiscal decentralization; and (d) fiscal capacity. Researchers studied History shows that the internal control system and no significant negative impact on financial performance through good governance (Julie, 2015). 


\section{Methods}

This study uses a level of explanation. Data collected through observation, questionnaires, interviews and documentation. The population in this study are all local work units (SKPD) in the Indonesian local government (Pangkep). The samples using total sampling technique in order to obtain a total sample of 245 people. Data were analyzed using analysis of Structural Equation Modeling (SEM), through the support of Analysis of Moment Structures (AMOS) Ver. 21.

\section{Results}

The model test results provide an explanation that the model has met the goodness of fit indices, for it is shown as follows:

Table 1. Goodness of fit indices overall model

\begin{tabular}{|c|c|c|c|}
\hline Goodness of fit index & Cut-Off Value & Results Model $*$ & Description \\
\hline$\chi^{2}$ - Chi-square & 316.819 & 305.751 & good \\
\hline Probability & $\geq_{0: 05}$ & 0113 & good \\
\hline CMIN / DF & $\leq 2: 00$ & 1,104 & good \\
\hline RMSEA & $\leq 0: 08$ & 0021 & good \\
\hline GFI & $\geq_{0.90}$ & 0919 & Marginal \\
\hline AGFI & $\geq_{0.90}$ & 0.889 & good \\
\hline TLI & $\geq_{0.92}$ & 0.991 & good \\
\hline CFI & $\geq_{0.92}$ & 0993 & . \\
\hline
\end{tabular}

Based on the goodness of fit indices, the model indicates suitability, which the acceptance rate was good and models to be accepted, so that the overall model is said to have been in accordance with the facts and can be analyzed further.

\section{Discussions}

$H_{1:}$ Human resources competencies is positive and significant effect on good governance

Human resources competencies is positive and significant effect on good governance can be evidenced by the coefficient value of 0,478 with a positive direction. Coefficients marked positive effect implies that the competencies of human resources is high, affecting the success rate of implementation of good governance. The result can also be proved with a probability value of $0,000<\alpha=0.05$. The first hypothesis testing results prove that the human resources competencies has a positive and a significant effect on good governance. Based on these results, we can conclude that the higher of human resources competencies, the real impact on the successful implementation of good governance, so that the first hypothesis proposed in this study acceptable or supported by empirical facts.

A human resources competency is a prerequisite in the implementation of good governance to improve the quality of governance and public service. The human resources competencies will facilitate and internalize the values of good governance for human resources are a decisive factor to achieve good governance. The human resources competency is high, affecting the success rate of implementation of good governance. An indicator of the most dominant form of human resource competence variable is the motive which is owned urge employees to run of job description in finance. Financial management staffs are required to have a clear motive in carrying out their tasks and responsibilities. Employees who have a motive to be able to complete its work in accordance with the policies, procedures and regulations so as to assist and facilitate the creation of good governance.

The results of this study are relevant to The Holy Qur'an: QS (Al-Isra, 840) that everyone should work in accordance with their expertise. Then the Lord knows who the true path is. The verse gives insight that everyone is required to work according to their expertise. Skills in question is appropriate competence, namely (motif, congenital factors, the concept of self, knowledge and skills) so that people who have the competence to be achieving good governance. Placement and selection of employees in realizing good governance requires the competent employee for the field work in order to realize good governance. 
This study supports the theory of orientation ability proposed by Spencer \& Spencer (1993: 3) that materialized professionalism of orientation ability called competencies built by the 5 elements of motives, traits, self-concepts, knowledge and skills. The relevance of this theory to the study conducted shows that the competence of the human resources of the deep financial management staff and inherent to the person and behaviour that can be predicted in a variety of circumstances and the job duties that support the realization of good governance. Managerial competence is positive effect on governance (Abbas, 2013). The findings were obtained denials from other researchers, that the auditor competency have a negative impact and not significant to governance (Hidayat, 2013).

\section{$\mathbf{H}_{2}$ : Information technology is positively and significantly effect on good governance}

Information technology is positively and significantly effect on good governance cannot be proven even though the coefficient of 0,027 with a positive direction. Coefficients marked positive influence means that information technology affects the rate of successful implementation of good governance. The result can also be proved with a probability value of $0,430>\alpha=0.05$. The second hypothesis testing results only prove that the information technology is positive but not significant effect on good governance. Based on these results, we can conclude that the second hypothesis proposed in this study, unacceptable or cannot be supported by empirical facts.

The results showed that some of SKPD in the Indonesian local government (Pangkep) have the hardware in accordance with the execution of the work is devoted to the financial administration purposes, the software used is sometimes difficult to adapt, update and management of data is often hampered and Internet networks are often disrupted. The hardware in question is the availability of computers as a vehicle or container used to apply information technology in the financial sector.

This study is relevant to The Holy Qur'an: QS (Al Mujadalah, 110) that expand it in assemblies, then Allah will give spaciousness for you. And when it is said: Stand ye, then stand it, Allah Still exalt those who believe among you and those who were given some degree of knowledge. And Allah SWT is Aware of what you do. Humans who have a high science will be appointed by God equal rank with those who have faith steady, resilient and strong. So people who use information technology will be capable of processing the world from the underdeveloped state towards a more advanced so as to realize good governance.

The findings of this study is different of Widjayanto (2001: 89), that information technology plays in providing useful information for decision-makers within the organization, including in terms of reporting to support decisionmaking process more effectively. This theory has no relevance to the discussion that the use of information technology is used to produce the financial statements and financial information in a timely, complete, accurate, and reliable according to regulations and promote good governance. The results of this study rejected the findings of previous investigators, that the utilization of information technology has a positive and significant impact on the financial reporting government reliability and precisely the time of reporting (Prasetyo, 2014). Supports the findings of other researchers, that the use of information technology is not in the context of good governance but it is only used as a tool to facilitate the work alone (Wigrantoro, 2003)

\section{$\mathbf{H}_{3:}$ Internal Control Systems is positive and significant effect on good governance}

Internal control system is positive and significant effect on good governance, provable with coefficient of 0,477 with a positive direction. Marked positive influence coefficient implies that a good internal control system could lead to an increase of good governance. The result can also be proved with a probability value of $0,001<\alpha=0.05$. Hypothesis testing results prove that all three of the internal control systems a positive and a significant effect on the implementation of good governance.

The condition is caused by the high-control environment that is needed to control a variety of activities and financial transactions so as to create sound financial management because it is supported by the values of integrity, commitment, organizational structure, delegation of authority and responsibility appropriate. Through the control environment implemented in the system of internal control in financial management then any financial activities and transactions be controlled, which will affect the implementation of good governance.

This study is relevant to The Holy Qur'an: QS (Al-Hujaraat, 6), that when it comes unto the wicked brings a message, check carefully that you do not inflict a disaster to a people without knowing the circumstances that cause you regret for the deed. Could be explained that the every individual looking for clarity about something (Tabayyun) in every news delivered. It gives insight to the financial management staff to exercise control over any transaction 
activity by checking in advance of any transaction truth before interpreting them in the financial statements so that transactions can be accounted for to support the implementation of good governance.

The findings of this study support the theory that financial control system activity must be controlled by the control system include the control environment, risk assessment, control activities, information and communication improvements and conducting monitoring. The relevance of this theory to the research conducted shows that the government's financial management organization, control systems are needed considering aspects of environmental control organization, anticipating various possible risks, to control procedurally by the rules, control the information that is transparent and accountable, and monitored in a controlled manner according to the principles of good governance (Boynton, 2008: 72). This study supports previous studies, that the internal control effectively is essential in supporting good corporate governance (Kosmas et al., 2011; Shah, 2012) then rejected the findings of other researchers that the internal control system was not significant on the financial statements quality of the local government (Shah, 2012; Rhodah, 2014; Dadang, 2015).

$\mathrm{H}_{\text {4: }}$ Human resources competencies is positive and significant on the financial management performance A human resources competency is positive and significant effect on the financial management performance, provable with coefficient of 0,285 with a positive direction. Coefficients marked positive effect implies that the human resources a competency is high, resulting in improved performance in the areas of financial management. The result can also be proved with a probability value of $0,042<\alpha=0.05$. The fourth hypothesis testing results prove that the human resources competencies a positive and significant effect on the financial management performance. Based on these results, we can conclude that the higher the competence of human resources, the real impact on the performance of financial management, so the hypothesis of the four proposed in this study, can be accepted or supported by empirical facts.

Human resources is one of the most important elements of the organization, therefore it must be ensured that the competence of human resources will provide an optimal contribution to the achievement of organizational goals. No matter how well a system that would be wasted just like that, if it is not supported by the competence of adequate human resources, especially human resources a competency which consists of motifs, heredity, self-concepts, knowledge and skills. This is because the motive which is owned urges employees to run of job description in finance.

Such evidence relevant to The Holy Qur'an: QS (At-Tawbah, 105), that the labour ye, then, Allah SWT and His Messenger, and the believers will see your work it, and you will be returned to God Recognizing the Unseen and the Visible and preached unto you what ye used to do. In carrying out the work mandated activities, to be undertaken in earnest by the competency to achieve optimal performance. As with the financial management staff should have the competence so as to achieve improved financial management performance.

Supports the independence theory developed Koch (2007: 48) that a reliable and professional individuals within the competence of independence. Financial management staffs are expected to have the independence to determine the motive of work, talent has become second nature and have the knowledge and skills practiced on the financial sector (Dadang, 2015). Auditor competences have a negative and insignificant effect on the financial performance (Hidayat, 2013; Prasetyo, 2014).

\section{$\mathrm{H}_{5:}$ Information technology positive and significant effect on the financial management performance}

Information technology is positive and significant effect on financial management performance cannot be proven even though the value of the coefficient 0.025 with a positive direction. Coefficients marked positive influence means that information technology affects the performance. The result can also be proved with a probability value of $0,519>\alpha=0.05$. The result proves that the information technology is positive but not significant effect on performance. Based on these results, we can conclude that the hypothesis of the five proposed in this study, unacceptable or cannot be supported by empirical facts.

The condition is caused because not all local work units (SKPD) in Indonesian local government (Pangkep) have the hardware in this case a computer specifically for the financial administration, the software used is sometimes difficult to adapt, update and management of data is often hampered and internet network often disrupted. Availability of support facilities enables the user to access the data required to complete the task of financial management staff. 
This study is relevant to The Holy Qur'an: QS (Al-Rahman, 33) that if you are able to penetrate (across) regions of the heavens and the earth, then pass, you cannot get through it with strength, that for anyone working in the field of science and technology, to seek to develop ability as far away as to penetrate (pass) regions of the heavens and the earth. If the use of information technology will be applied it is necessary to prepare the infrastructure ranging from hardware, software, data management and network so that through the utilization of the information well then be presented financial data that can be distributed to all users of information through the Internet.

This study supports the usefulness of decision theory (Belkoui, 2001) that there should be a system that provides information; unlike systems that required either to base decisions or base to regain the consequences of the decision. The capability of information technology has a significant relationship with the financial performance of the banking organization (Kabiru et al., 2015; Rahman \& Fachri, 2016). Utilization of information technology has a positive and significant impact on the reliability financial reporting and precisely the time of reporting (Prasetyo, 2014). Use of information technology is not in the context of good governance but it is only used as a tool to facilitate the work alone (Wigrantoro, 2003)

\section{$H_{6:}$ Internal control system is positive and significant effect on the financial management performance}

Internal control system has a positive effect on the financial management performance can be proved by the coefficient of 0,196 with a positive direction. Marked positive influence coefficient implies that a good internal control system, resulting in an increase in the financial management performance. The result can also be proved with a probability value of $0,048<\alpha=0,05$. Hypothesis testing results of the sixth proved that the internal control system is positive and no significant effect on the financial management performance. Based on these results, we can conclude that the better the system of internal control, the real impact on the financial management performance, so the six hypotheses can be accepted or supported by empirical facts.

Implementation of the internal control system will realize the integral process on the actions and activities that are carried out continuously by the management and all employees of the financial manager to provide reasonable assurance for the achievement of organizational goals through effective and efficient, the reliability of financial reporting, the safeguarding of state assets, and obedience against the legislation. Factors causing significant influence on the performance of the internal control system of financial management is the control environment which is a controlling various financial activities and transactions within the organization. Control environment plays a very important because it will determine the sustainability of internal control. The implementation of internal control systems, leadership is responsible for developing policies, procedures, and practices of detail to suit the activities of government agencies and to ensure that these elements have merged and become an integral part of the activities of government agencies so that the control environment is needed to control a variety of activities and transactions finance so that each activity and financial transactions be controlled which will impact on improving the financial management performance.

This study is relevant to The Holy Qur'an: QS (Al-Hashr, 18) that fear Allah SWT and let every self pay attention to what he has done for tomorrow (the here after); and fear Allah, verily Allah is Aware of what you do. Everyone should pay attention to what he has done today for the sake of tomorrow. Allah SWT gives direction to every person of faith to design a plan of what to do in the future, so tomorrow should be better than today. In the Islamic view everything should be well planned and organized. no exception in terms of financial management so that the necessary internal control system that is planned and organized in order to provide better results in the future.

The internal control accounting has positive and significant impact on the financial reporting government reliability (Prasetyo, 2014; Rosma, 2014; Obal \& Salim, 2016). The internal control system was not significant influence on the quality of local government financial statements (Ashmir, 2012; Rhodah, 2014; Dadang, 2015).

\section{$\mathrm{H}_{7}$ : Good governance has a positive and significant effect on financial management performance}

Good governance has a positive effect on the financial management performance of can be proved by the coefficient of 0,472 with a positive direction. Coefficients marked positive effect implies that good governance is high, resulting in an increase in the financial management performance. The result can also be proved with a probability value of $0,004<\alpha=0,05$. The results of hypothesis testing proved that good governance has a positive and significant effect on the financial management performance. Based on these results, we can conclude that the better good governance, the real impact on the financial management performance, so the hypothesis seventh proposed in this study, can be accepted or supported by empirical facts. 
The condition is caused due to good governance resulted in an increase in the financial management performance. A transparency is the principle of transparency in the financial management area. Openness is characterized by their open attitude by the government to provide information on the financial management of each process and the implementation of financial management. This is supported by the government's efforts to provide useful information for the public as well as facilitate the public to obtain such information by way of providing information through the mass media or electronic media, as well as provide information to parties in need.

This study is relevant to The Holy Qur'an: QS (Al-Hadid, 25), that we have sent Our Messengers with the real evidence and we have sent down with them the Al-Qur'an, so that people can carry out justice. And we have created an iron that contained her great strength and a wide range of benefits to the people (that they use iron) and that Allah SWT may know who help (religion) Him and His messengers, when God has not seen. Surely Allah is Strong, Mighty. The Qur'an is the source of truth that is recognized by common sense again straight so that the necessary financial management of justice which is the principle of good governance.

The findings of this study support the ordinary theory (Dalton et al., 2006) that the basic principle of governance is the order in formulating any implementation that can be evaluated according to the program's objectives and activities. The relevance of this theory to the research conducted shows that the financial management of government organizations, the need for regularity so that organizational goals can be evaluated based on the implementation of all programs and activities. Empirical evidence shows that good governance is a positive and significant effect on the financial management performance (Sri Fadilah, 2013; Igor Todor, 2013; Prasetyo, 2014; Husmaruddin, 2015). The findings were obtained denials from other researchers, that good corporate governance is not significant effect on the financial performance (Makki \& Lodhi, 2014).

$H_{8:}$ Human resource competencies is significant effect on financial management performance: The mediating role of good governance

A human resource competency is significant effect on financial management performance: The mediating role of good governance with a coefficient of 0.511 and a significance level of $0,017<0,05$ so that it can be said that the human resource competencies directly and not immediately able to provide a real impact on improving the performance of financial management. This suggests that a good of human resource competencies encourage increased good governance, so the impact on the improved of financial management performance. Good governance in the research model is said to be mediating variables, which means that the competence of human resources have a significant effect on the financial management performance. Human resource competencies are significant effect on good governance, and good governance affect significantly on the financial management performance. So that it can be said that the Human resource competencies directly and indirectly can give a real impact on improving the financial management performance.

This study is relevant to The Holy Qur'an: QS (Al-Nahl, 97), that those who do righteous deeds, whether male or female in a state of faith, verily, We shall give a good life and verily We shall recompense them with a reward which is better than what they have done, that everyone should have the competence in accordance with the field work. In conjunction with this research is that financial managers develop their potential so that it will have an impact on the performance of financial management through good governance.

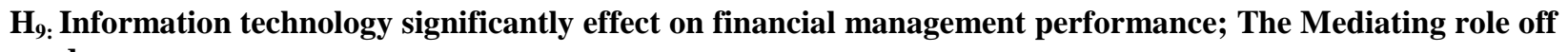
good governance.

Information technology significantly effect on financial management performance; The Mediating role of good governance with a coefficient value of 0,038 and a significance level of $0,441>0.05$ so that it can be said that information technology directly and indirectly, cannot provide a real impact on improving the financial management performance. This shows that information technology does not encourage increased good governance so as not to impact on improved the financial management performance.

Information technologies indirectly through good governance have a positive effect and are not significant on improvement the financial management performance. Indirect application of information technology through good governance was not significant effect on the financial management performance in accordance with the financial independence, dependence, fiscal decentralization and fiscal capacity. 
This study is relevant to The Holy Qur'an: QS (Al-Mulk, 19), that if they did not pay attention to the birds that develops and shut its wings above them? No holding in (air) other than the Merciful He is Seer of Everything, which in fact there are many things that can be developed through reasonable human mind, including an aircraft which is a manifestation of the use of information technology in this case the computers and other devices.

This study relevance on Theory of Reasoned Action (TRA) (Fishbein \& Ajzen, 1975) that a person will use information technology if the technology useful and can improve the performance of the person. Utilization of information technology in question such as the use of computers and software optimally, will impact on transaction processing faster and calculations will also have a high level so high that will lead to improvements in the quality of financial reporting is more reliable due to the use of technology will reduce errors that are material.

\section{$H_{10}$ : Internal Control System significantly effect on financial management performance; the mediating role of Good Governance.}

Internal control system has a significant effect on financial management performance: the mediating role of good governance with a coefficient of 0.421 and a significance level of $0,021<0,05$ so that it can be said that the internal control system can give a real impact on financial management performance. This shows that the internal control system to establish good governance that better so that ultimately resulted in increased government public financial management performance. Good governance in the research model is said to be as a mediating variable. This means that the internal control systems have real impact on good governance, that the internal control system indirectly through good governance has a positive and significant effect improvement on financial management performance.

This study is relevant to The Holy Qur'an: QS (An-Nisa, 58), that Allah SWT sent you convey the message to those who deserve it, and (told you) if it establishes the law among men that you assign to the fair. Verily Allah gives his best teaching you. God is All-Hearing, All-Seeing. That the Islamic view of financial management should be in accordance with the legislation in force, especially with regard to the allocation of the budget must be in accordance with the plans that have been made by applying the principles of justice.

\section{Conclusion and recommendations}

Human resource competencies directly influence positively and significantly related to good governance, that employee financial managers have motives that they can complete the work in accordance with the policies, procedures and regulations so as to assist and facilitate the creation of good governance. Information technology directly influence positively and significantly to good governance, that the availability of computers as a vehicle or container used to apply information technology in the financial sector but not significant because the computer that is still used for work that is more, this will result in the slow completion work in the field of financial management.

Internal control systems directly influence positively and significantly related to good governance, that the control activities where control of all activities performed by employees of financial management based on the policies, procedures and rules applicable in accordance with the standards that have been established so that all errors and fraud can be avoided for it will contribute to the creation of good governance.

Human resource competencies directly positive and significant impact on the performance of the financial management of the area, that the competencies of human resources is absolutely necessary in order to improve the performance of financial management. In improving the performance of financial management requires human resources who understand and are competent in the field of finance. Information technology directly influence positively and significantly to the performance management of local finances, that information technology is less optimally applied in support performance improvement of financial management so that the necessary repairs and improvements to the hardware, software, data management and networking in improving the performance of financial management.

Direct internal control systems and a significant positive effect on the performance of the financial management of the area, that the internal control system has been well implemented so as to support improved financial management performance. Internal control systems are needed by considering revamping the organization's environmental improvement, anticipating possible risks in the activities and financial transactions. Good governance is directly positive and significant impacts on the performance of the financial management of the area, that employee financial manager observe and comply with applicable regulations that will improve the financial 
management performance of. The competence of human resources is positive and significant effect on the financial management performance.

The human resources competence has been actualized exactly so that is positive and significant through good governance the financial management performance. Information technology has a positive and no significant effect on the financial management performance. The information technology has not been fully implemented so that the effect is not significant either through good governance on the financial management performance. An internal control system has a positive and significant effect on the financial management performance, that the internal control system has been implemented well so that is positive and significant through good governance on the financial management performance. This study contributes to the financial management staff to actualize by maintaining competence and knowledge in his motive possession at this time. Optimizing the utilization of information technology ranging from improved network, upgrading software (SIMDA), data management and provide the hardware (computer) according to the required specifications and functions that will lead to the implementation of good governance.

Provide opportunities to employees of financial managers to improve their competence due to its competence will have an impact on the implementation of good governance. Internal control system applied to all aspects of the scope of the organization to minimize the occurrence of errors in the financial management that will realize good governance. Implementation of good governance need to be maintained from the principle of the rule of law, the strategic vision, accountability, transparency, effectiveness and efficiency, responsibility and consensus. Keeping all employees of financial operators continue to develop their competence so as to create good governance, which in turn will have an impact on improving the financial management performance.

It is expected that every employee financial managers use information technology well according to existing procedures in support of the implementation of good governance to improve the performance of financial management. Promote the adoption of internal control systems are integrated into all the components of the local government institutions to realize good governance that will have an impact on the financial management performance of the clean, transparent and accountable.

\section{References}

1. Abbas, Ibnu. (2013). Affected of Financial Management and Auditor Competence Toward Corporate, Satisfaction and financial Performance. Journal of Business Research

2. Ashmir Shah,( 2012). The Affectof Internal Control System toward Finance Management and Corporate Governance Increasing of Performance.International Journal Of Performance Management Vol 18 No. 8. 133-154

3. Belkaoui, Ahmed R.(2001). Teori Akuntansi, Edisi 4, Jilid 2. Alih Bahasa. Mawinta, Hajayanti Widiastuti, Heri Kurniawan, Alia Arisanti. Penerbit. Salemba Empat

4. Boynton, AA, (2008). Fundamental of Management Accounting. Fourth Edition. Richard D. Irwin, Inc, Homewood, Illinois

5. Dadang Suwanda, (2015). Factor Effecting Quality of Local Government Financial Statement to Get Unqualified Opinion (WTP) of Audit Board of The Republic of Indonesia (BPK). Research Journal of Finance and Accounting. Vol 6 No. 4, 139-157.

6. Dalton, D. R., Daily, C. M., Ellstrand, A. E. and Johnson, J. L. (1998) Meta-Analytic Reviews of Board Composition, Leadership Structure, and Financial Performance, Strategic Management Journal, 24, 269290.

7. Fishbein \& Ajzen, (1975). Belief, Attitude, Intentions and Behavior: an introduction to theory and research. California: Addison-Wesley. Publishing Company, Inc

8. Freeman, R. E. (1984). Strategic Management: A Stakeholder Approach, Boston,. Pitman

9. Halim, Abdul. (2004). Management of Regional Finance, Revised edition. Yogyakarta: UPP AMP YPKN

10. Henderson \& Bruce, (2002). Performance Measure for Not for Profit Organizations(NPOs). Journal of Accounting.

11. Henderson, D., Chase B, \& Woodson, B. (2002). Performance measures for NPOs: How one organization developed a way to collect meaningful information?. Journal of Accountancy, 193(1), pp. 63-68.

12. Hevesi, G. Alan. (2005). Standards for Internal Control in New York State. Government. www.osc.state.ny.us. 
13. Hidayat, Rahmat. (2013). The Influence of Financial Management, Auditor Competence, Internal Control and Job Satisfaction on Corporate Governance and Financial Performance of Banking Industry PT. National Bank of Indonesia Branch Medan. Journal of Financial Management Vol 9. May No.4

14. Husmaruddin (2015). Influence of Budgetary Participation, Financial Supervision and Leadership Style on Good Governance and Financial Management Performance of Regency of South Sulawesi Province. Unpublished Dissertation, PPs-UMI, Makassar

15. Igor Todorovic, (2013). Impact of Corporate Governance on Performance of Companies.Montenegring Journal Of Economic Vol 9 No. 2.. pp 47-53.

16. Indrawati, (2012). Principles of Good Financial Governance in State Financial Management in the Framework of Realizing Clean Governance. Perspective Journal Vo. XVII No. 12. September Edition, 201 211

17. International Organization of Supreme Audit Institutions (INTOSAI), (2004), “Guidelines for Internal Control Standards for The Public Sector", Intosai general Secretariat - Rechnungshof (Austrian Court of Audit) Dampfschiffstrasse 2, A-1033 Vienna, Austtria.

18. Jensen, M. \& Meckling, W., (1976), Theory of the Firm: Managerial Behavior Agency Cost, and Ownership Structure, Journal of Finance Economics 3, 305-360.

19. Julie Abdullah, (2015). Influence of Internal Control System and Managerial Competence to Good Governance and Financial Performance of Gorontalo Provincial Government. Unpublished Dissertation, PPs-UMI, Makassar

20. Kabiru J. Ringim, Mocd R. Razalli \& Norlenna Hasnan.(2015). The Relationship between Information Technology Capability and Organizational Performance in Nigerian Banks. International Journal Of Bussiness Research and Development Vol 4 No. 2. pp 1-10.

21. Koch, Berk. (2007). Organization and Management. Rotledge and Kegan Paul, London.

22. Kooiman, J., (ed), (1993), Modern Governance: New Government-Society.

23. Kosmas Njanike, Margaret Mutengezanwa, \& Fungai B. Gombarume, (2011). Internal Control in Ensuring Good Corporate in Financial Institutions. Annals of The University of Petrosani, Economics. Vol 11 No. 11. 187-196

24. Kurniawan, Agung. (2005). Transformation of Public Service. Yogyakarta: Update.

25. Lestari \& Zulaikha, (2007). Influence of Information Technology Relatedness to Company Performance with Knowledge Management Capability as Intervening variable (Empirical Study on Banking Company in Central Java). National Symposium on Accounting X Makassar.Mahmudi, (2007). Manajemen Kinerja Sektor Publik. UPP AMP YKPN, Yogyakarta

26. Majuta Jodas Mamogale, (2014).Financial Performance of Local Government in Limpopo Province. African Studies Quarterly. Vol 5 Issue 1,. Pp 71-92.

27. Makki, Muhammad Abdul Majid \& Lodhi, Suleman Aziz. (2014). Impact of Corporate Governance on Intellectual Capital Efficiency and Financial Performance. Pakistan Journal of Commerce and Social Science.Vol. 8 No.2. 2014. pp:305-330.

28. Manaroinsong, Johny. (2012).The Personal Factor Particularly The Individual Competence And Management Factor Including The Reward and Punishment System Related To The Efficiency As Marked By The Work Satisfaction and Financial Performance, and The Local Financial Independence. Jurnal Aplikasi ManajemenVol 9, No 3. 2012.

29. Mardiasmo. (2004). Otonomi dan Manajemen Keuangan Daerah. Yogyakarta: Andi.

30. Obal Usang Edet Usang \& Basariah Salim, (2016). Dimensions of Internal Audit Quality and Performance of Local Government in Nigeria. Asian Social Science. Vol.12 No.4,:28-36

31. Prasetyo, Aditya Rachman. (2015). Effect of Human Resource Capacity, Utilization of Information Technology, Internal Control of Accounting and Good Corporate Governance Against the Reliability and Timeliness of Government Financial Reporting. Journal of Accounting \& Finance Unja, Vol 1, No 1, .3752.

32. Prawirosentono, Suryadi. (2008). Performance Employee Policy, Yogyakarta: BPFE.

33. Rahman, Abdul \& Fachri, Zulkifli. (2016). Region's Financial Accounting Information System and The Quality of Local Government Financial Reports. International Journal Of Information Management and Bussiness Review Vol 8 No. 4.. pp 64-68.

34. Republic of Indonesia (2006). Minister of Home Affairs Regulation No. 13 of 2006 on Regional Financial Management. 
35. Republic of Indonesia (2011). Regulation of the Minister of Home Affairs Number 21 of 2011 on the Second Amendment of the Regulation of the Minister of Home Affairs Number 13 of 2006 concerning Guidelines on Regional Financial Management.

36. Republic of Indonesia (2017) Act. Of the 1945 Constitution of the State of the Republic of Indonesia.

37. Republic of Indonesia. (2000). Government Regulation of the Republic of Indonesia Number 101 of 2000 on Education and Training of Position of Civil Servants.

38. Republic of Indonesia. (2008). Government Regulation Number 60 of 2008 regarding. Internal Control System.

39. Rhodah O. Onyango, (2014). Influence of Internal Controls on Performance of County Governments in Kenya. University Of Nairobi

40. Rosma Simangunsong, (2014). The Impact of Internal Control Effectiveness and Internal Audit Role toward the Performance of Local Government.Research Journal of Finance and Accounting. Vol. 5 No.7, 2014. pp:50-58

41. Setyawan, Salam, Dharma. (2004). Management of Indonesian Government. Jakarta: Publisher Djambatan

42. Spencer, Lyle \& Signe M. Spencer. (1993). Competence at Work, Models For Superior. Performance. Canada : John Wiley \& Sons, Inc.

43. Sri Fadilah, (2013).The Influence of Good Governance Implementation to Organization Performance. The InternationalJournal of Social Sciences. Vol 7 No. 1.. 33.

44. Stoner, James A.F. (2006). Manajemen. Jilid I. Edisi Keenam. Salemba Empat, Jakarta.

45. Sutrisno, Edy. (2009). Human Resource Management. Jakarta: Kencana

46. The Committee of Sponsoring Organization of the treadway Commission, COSO (1992): COSO - Internal Control Integrated Framework, The Committee of Sponsoring Organization of the treadway Commission

47. The United Nations, Statistics Division (2000) good governance. United Nations Development Programme (UNDP).

48. Triandis, H.C. (1980). Value, Attitudes and Interpersonal Behavior. Lincoln: University of Nebraska Press.

49. Widjayanto, Nugroho, (2001). Accounting Information Systems. Jakarta: Erland.

50. Wigrantoro, (2003). Utilization of Information Technology in the Implementation of Good Governance. Seminar Paper "Good Governance Paradigm in a Competitive, Democratic and Transparent Information Era" was organized by Gunadarma University, Jakarta, on June 11.

51. Wilkinson, Josep W, (2000), Accounting Information System Essential Concept and Application 4th Edition, John Willey \& Sons Inc, New York- USA

52. Winarno, Mardisa. (2002). Company Internal Audit. Publisher Cipta Bumi Persada, Surabaya. 